Research

\title{
Malaria vectors in Angola: distribution of species and molecular forms of the Anopheles gambiae complex, their pyrethroid insecticide knockdown resistance (kdr) status and Plasmodium falciparum sporozoite rates
}

\author{
Nelson Cuamba ${ }^{1,2}$, Kwang Shik Choi ${ }^{1}$ and Harold Townson*1
}

Address: ${ }^{1}$ Liverpool School of Tropical Medicine, Pembroke Place, L3 5QA, Liverpool, UK and ${ }^{2}$ Ministério da Saúde, Instituto Nacional de Saúde, C.P 264, Maputo, Mozambique

Email: Nelson Cuamba - ncuamba@yahoo.com; Kwang Shik Choi - kschoi@liverpool.ac.uk; Harold Townson* - htownson@liverpool.ac.uk

* Corresponding author

Published: 18 January 2006

Malaria Journal 2006, 5:2 doi:10.1186/1475-2875-5-2

This article is available from: http://www.malariajournal.com/content/5/I/2

(C) 2006 Cuamba et al; licensee BioMed Central Ltd.

This is an Open Access article distributed under the terms of the Creative Commons Attribution License (http://creativecommons.org/licenses/by/2.0), which permits unrestricted use, distribution, and reproduction in any medium, provided the original work is properly cited.
Received: 13 October 2005

Accepted: 18 January 2006

\begin{abstract}
Background: Malaria is by far the greatest cause of morbidity and mortality in Angola, being responsible for $50 \%$ of all outpatient attendance and around $22 \%$ of all hospital deaths, yet by 2003 only $2 \%$ of under- 5 s used insecticide-treated nets. Entomological studies are an essential foundation for rational malaria control using insecticide-treated nets and indoor residual spraying, but there have been no published studies of malaria vectors in Angola over the 27 years of the civil war, to its end in 2002. This paper describes studies arising from a WHO-sponsored visit in support of the National Malaria Control Programme.
\end{abstract}

Methods: During April 200I, mosquitoes were sampled by indoor pyrethrum spray collection from four sites in the semi-arid coastal provinces of Luanda and Benguela and two sites in Huambo province, in the humid tropical highlands. Collections took place towards the end of the rainy season and were used to determine the Anopheles species present, their sporozoite rates and the frequency of a $k d r$ allele conferring resistance to pyrethroid insecticides.

Results: A PCR test for the Anopheles gambiae complex showed a preponderance of An. gambiae, with indoor resting densities ranging from 0.9 to 23.5 per house. Of $403 \mathrm{An}$. gambiae identified to molecular form, $93.5 \%$ were $\mathrm{M}$-form and $6.5 \% \mathrm{~S}$-form. $\mathrm{M}$ and $\mathrm{S}$ were sympatric at 4 sites but no $\mathrm{M} /$ S hybrids were detected. The highest proportion of S-form (20\%) was in samples from Huambo, in the humid highlands. Anopheles funestus was found at one site near Luanda. The sporozoite rate of mosquitoes, determined by an ELISA test, was $1.9 \%$ for An. gambiae $(n=580)$ and $0.7 \%$ for An. funestus $(n=140)$. Of $218 \mathrm{An}$. gambiae (195 M-form and $23 \mathrm{~S}$-form) genotyped for the West African $k d r$-resistance allele, all were homozygous susceptible.

Conclusion: An. gambiae M-form is the most important and widespread malaria vector in the areas studied but more extensive studies of malaria vectors are required to support the malaria control programme in Angola. These should include standard insecticide resistance biossays and molecular assays that can detect both metabolic resistance and target site insensitivity. 


\section{Introduction}

In West Africa, Anopheles gambiae, Anopheles arabiensis and Anopheles funestus are the main vectors of malaria, although Anopheles melas, a member of the An. gambiae complex, is known to be a malaria vector in some coastal areas [1-3].

It has been shown that An. gambiae comprises two molecular forms, $\mathrm{M}$ and $\mathrm{S}$, recognisable from rDNA sequence differences, either in the intergenic spacer [4] or in the internal transcribed spacer $[5,6]$. The genetic characteristics of these forms and their known geographical distribution have recently been reviewed [6]. Whilst there is considerable restriction to gene flow between these forms, reproductive isolation is not complete, with the result that the knock-down resistance allele $(k d r)$, which confers resistance to pyrethroid insecticides and which is assumed to have first developed in the S-form, has subsequently passed from the S-form to the M-form, presumably due to hybrid formation and consequent introgression $[7,8]$. Recent studies suggest that the resistance kdr allele is now spreading in the M-form in West Africa [9]. The S-form is known to be the most common and widespread in subSaharan Africa, and is the only form found in eastern Africa. The distribution of the forms is reasonably well studied in West Africa from Senegal to Cameroon, but less is known of their distribution further south in western Africa.

Malaria is endemic throughout much of Angola territory, and is by far the highest cause of morbidity and mortality. During the period from 1999 to 2002 (last year for which data are available) there were 1.47 million cases of malaria annually, out of a mid-period population of c.11.4 million. Malaria continues to be responsible for $50 \%$ of all outpatient attendance and around $25 \%$ of all hospital deaths, yet by 2003 only $2 \%$ of under-5s used insecticide-treated nets [10]. Due to the successive wars, malaria vector control activities and operational studies have been interrupted for decades, with a consequent lack of basic information on malaria vectors. This lack of information plus the dearth of skilled malaria entomologists are potential impediments to the goal of the National Malaria Control Programme of scaling up the use of insecticide-treated nets (ITNs) as a major strategy for the control of malaria. Indoor residual spraying (IRS) of insecticides was used in 4,000 households in 2002 [10] but extended use of this technique, which has been effective in other regions of southern Africa, would also be limited by inadequate knowledge of vector species distribution and the lack of skilled staff.

During April 2001, the senior author (NC) visited Angola at the request of $\mathrm{WHO}$, to assist in "strengthening malaria vector control especially the promotion of insecticide-

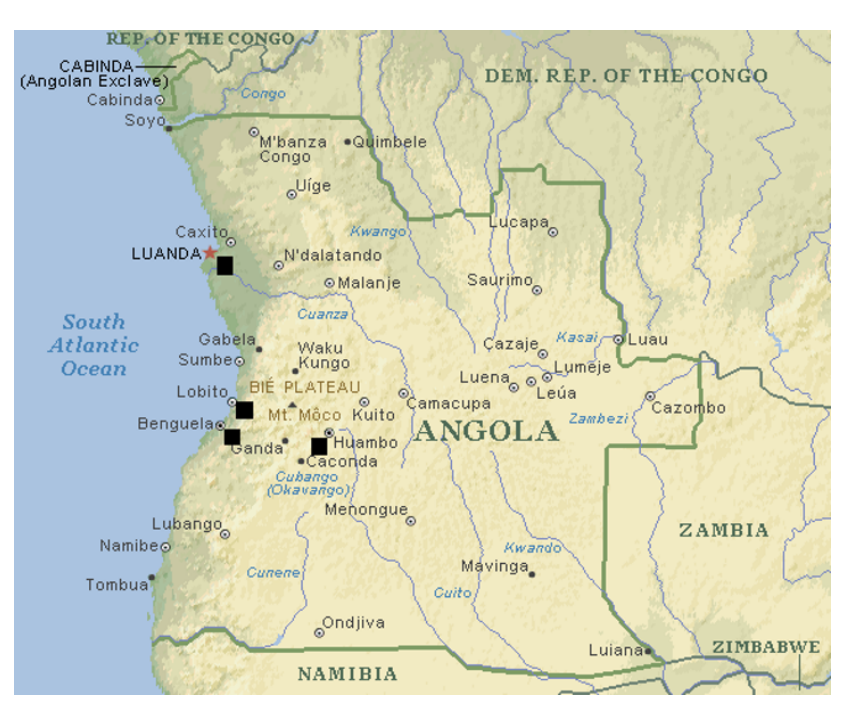

\section{Figure I}

Map showing the localities in Angola where anopheline mosquitoes were collected: Luanda (Samba and Cacuaco), Lobito (São Pedro), Benguela (Cawanga and Bela Vista) and Huambo (São Jose and Cazenga).

treated bed nets". As one part of this mission, a rapid mosquito survey was carried in some of the malarious regions of the country with a focus on areas around the capital Luanda, the semi arid coastal cities of Benguela and Lobito and Huambo city in the tropical highlands. The main malaria transmission season in Angola lasts from November to April. This paper is based on data from that rapid survey and subsequent laboratory studies. The primary objective has been to gather information on species composition within the An. gambiae and An. funestus complexes, their potential role in malaria transmission and to provide information on the status of $k d r$-based resistance to pyrethroids in An. gambiae in Angola.

\section{Mosquito collections}

Mosquitoes were collected towards the end of the rainy season during the period 11-19 April 2001 from seven localities in Angola, all close to or within urban areas; five in the semi-arid, coastal strip south from Luanda to Benguela and two in the humid tropical highlands of Huambo Province, (see Figure 1). viz: Funda in the coastal municipality of Cacuaco $\left(08^{\circ} 51^{\prime} \mathrm{S} ; 13^{\circ} 34^{\prime} \mathrm{E}\right)$ just northeast of Luanda; Samba, a municipality of Luanda $\left(08^{\circ} 59^{\prime}\right.$ S; $\left.13^{\circ} 15^{\prime} \mathrm{E}\right)$; São Pedro, in the municipality of Lobito $\left(12^{\circ} 20^{\prime} \mathrm{S} ; 13^{\circ} 34^{\prime} \mathrm{E}\right)$; Cawango and Bela Vista, in the municipality of Benguela ( $\left.12^{\circ} 34^{\prime} \mathrm{S} ; 13^{\circ} 24^{\prime} \mathrm{E}\right)$; São Jose and Cazenga, in the city of Huambo $\left(12^{\circ} 47^{\prime} \mathrm{S} ; 15^{\circ} 44^{\prime}\right.$ E).

Indoor resting mosquitoes were collected from houses using pyrethrum spray collections and stored dry over sil- 
Table I: Numbers and densities of adult mosquitoes of An. gambiae s.I., An. funestus s.l. and Culex from indoor pyrethrum spray collections.

\begin{tabular}{|c|c|c|c|c|c|c|c|c|}
\hline \multirow[b]{2}{*}{ Muncipality } & \multirow[b]{2}{*}{ site } & \multirow[b]{2}{*}{ no. of houses } & \multicolumn{2}{|c|}{ An. gambiae s.l. } & \multicolumn{2}{|c|}{ An. funestus s.l } & \multirow{2}{*}{$\begin{array}{r}\text { Culex sp. } \\
\text { no. }\end{array}$} & \multirow[b]{2}{*}{ no. per house } \\
\hline & & & no. & no. per house & no. & no. per house & & \\
\hline \multirow[t]{2}{*}{ Benguela } & Bela Vista & 24 & 124 & 5.2 & 0 & - & 0 & - \\
\hline & Cawango & 33 & 254 & 7.7 & 0 & - & 133 & 4.0 \\
\hline Cacuaco & Funda & 29 & 29 & 1.0 & 315 & 10.9 & 0 & - \\
\hline Lobito & São Pedro & 35 & 824 & 23.5 & 0 & - & 69 & 2.0 \\
\hline \multirow[t]{2}{*}{ Huambo } & Cazenga & 34 & 31 & 0.9 & 0 & - & 105 & 3.1 \\
\hline & São Jose & 37 & 121 & 3.3 & 0 & - & 313 & 8.5 \\
\hline
\end{tabular}

ica gel in Eppendorf tubes. In Samba, only larvae were collected; these were obtained from a rainwater pool and preserved in $80 \%$ alcohol.

\section{Identification of species, molecular forms and kdr mutations}

DNA was extracted from individual mosquitoes [11] and members of the An. gambiae complex were identified to the species-level and molecular-form using the protocol of Fanello et al. [12]. Identification of specimens of $A n$. funestus s.l. was performed with the primers and protocol of Koekemoer et al. [13]. All identifications of $M$ and $S$ forms were conducted twice (by NC and KSC).

The presence of $k d r$ alleles conferring knock-down resistance in West Africa was assessed using the primers and protocol of Martínez-Torres et al. [14]. The PCR products of samples collected in the field in Angola were run on agarose gels with control samples known to represent homozygous resistant $(\mathrm{kdr} / \mathrm{kdr})$, heterozygous $(\mathrm{kdr} /+)$ and homozygous susceptible $(+/+)$ individuals. The PCR amplification products consisted of an internal control of 293 bp present in all specimens, a susceptible allele product of $137 \mathrm{bp}$ and a resistance allele $(k d r)$ band of $195 \mathrm{bp}$. To eliminate errors in scoring, all $k d r$ allele assays were carried out twice (by NC and KSC) and discrepancies checked.

Sporozoites rates for Plasmodium falciparum were determined by the ELISA method $[15,16]$, using the head and thorax of individual female mosquitoes.

\section{Results}

The numbers of mosquitoes found resting indoors at each locality in Angola are shown in Table 1; data for Culex spp are included for comparative purposes but are not discussed further here. The numbers of individuals for the different species and/or molecular forms of the An. gambiae complex are shown in Table 2. Of the An. gambiae s.s. collected, the $\mathrm{M}$-form was predominate, representing $93.5 \%(n=403)$. The S-form was restricted to localities in the municipality of Benguela on the coast, where it comprised $3.8 \%(\mathrm{n}=184)$, and Huambo in the humid high- lands, where it comprised 20\% ( $=94)$ of An. gambiae s.s. collected. These differences in proportions of S-forms between coastal and highland sites are significant ( $\mathrm{p}<$ 0.001). No M/S heterozygotes were found.

An. melas was found, together with An. gambiae M-form, resting indoors in the coastal area of Cacuaco. In the larval collection from Samba, one An. arabiensis was found along with 21 specimens of An. gambiae M-form. Forty-six specimens of An. funestus s.l. from indoor collections in Cacuaco were identified to species; all proved to be $A n$. funestus s.s.

The results of assays for kdr resistance alleles in An. gambiae $\mathrm{M}$ and $\mathrm{S}$-forms are shown in Table 3. All 218 individuals examined were exclusively of the homozygous susceptible genotype.

The results of sporozoite ELISA assays are shown in Table 4. Adult mosquitoes collected from Huambo had to be preserved in alcohol and hence were unsuitable for ELISA. The overall infection rate was $0.7 \%$ in An. funestus ( $\mathrm{n}=$ $140)$ and $1.9 \%$ in An. gambiae ( $\mathrm{n}=580)$.

\section{Discussion}

Little is known of malaria vectors in Angola and, with one exception (discussed below), all published studies preceded the war of independence and subsequent civil war, which finally ended in 2002. Although Angola is building up a cadre of technical staff to assist in the distribution of ITNs [10], as yet it has insufficient numbers of skilled malaria entomologists and data on malaria vectors remains scarce. Thus, despite the limitations of a rapid, time-limited survey, the data shown are a useful guide to the further studies needed for effective implementation of vector control.

A recent analysis of published and unpublished data on the distribution of the molecular forms of An. gambiae $[6,17]$ has demonstrated how the M-form shows the greatest latitudinal range in West Africa, being the only form recorded in the Sudan and Sahel savannah areas of northern Senegal. The predominant domiciliary malaria vector 
Table 2: Numbers of $M$ and $S$ molecular forms of An. gambiae collected in Angola. Data are for indoor pyrethrum spray collections, except where noted.

\begin{tabular}{lcccc}
\hline Locality & Site & Molecular form & Sotals \\
& & 115 & 3 & 118 \\
Benguela & Cawango & 62 & 4 & 66 \\
& Bela Vista & 91 & 0 & 91 \\
Lobito & São Pedro & 13 & 0 & 13 \\
Cacuaco & Funda* & 21 & 0 & 21 \\
Luanda & Samba** & 57 & 7 & 34 \\
Huambo & São Jose & 18 & 12 & 30 \\
Totals & Cazengue & 377 & 26 & 403 \\
\hline
\end{tabular}

* 26 of 29 specimens successfully amplified; 13 of these were An. melas

** 22 identified as larvae; one of these was An. arabiensis

in our study was An. gambiae M-form. The low proportion of the S-form among An. gambiae in Benguela and its absence in samples from Lobito and Luanda mirrors the findings in Carrara et al. [17] and almost certainly reflects the semi-arid climate of the coastal provinces. The more humid tropical highlands around Huambo would favour the greater proportion of S-form (20\%) found there. In the published abstract of Carrara et al. [17] data are given on the distribution of M and S-forms from sites in Angola. For samples from around Luanda and Namibe, the Mform was overwhelmingly predominant. Namibe is close to the northern extension of the Namib desert. Sample sizes from inland sites in their study were very small ( $\leq$ 18) but showed a preponderance of S-form.

In our study we found a sporozoite rate in An. gambiae s.s. of $1.9 \%$ (95\% CI $0.8-3.0)$, which is based on samples from localities where the $\mathrm{M}$-form was predominant (97.6\%). Despite these samples being collected in the rainy season when nullipars predominate, it is nevertheless higher than the $0.4 \%$ for An. gambiae s.s. in the studies of Carrara et al. [17].

Only a single An. arabiensis specimen was found in this study, in a larval collection. The scarcity of this species in samples from a semi-arid region that might have been expected to favour this species may be a reflection of seasonal abundance or exophily, although it is notable that this species was also scarce in the studies of Carrara et al. [17].

There is evidence (reviewed in [6]) that throughout its distribution, the M-form may more often be found in semipermanent and man-made breeding sites. This suggests that consideration should be given to suitable environmental modifications to reduce mosquito breeding in the coastal peri-urban centres of Angola where M-form predominates. Environmental management would form a useful adjunct to ITNs and the residual spraying of houses [18]. Where S-form is more common, as in the highlands around Huambo (this study) or in the humid tropics of the Cabinda enclave [17], such measures could be less effective, since in many parts of its range, S-form readily breeds in small rain-dependent sites that are not as amenable to environmental management. In West Africa, there is evidence of varying levels of hybridisation between $\mathrm{M}$ and S-forms, a mechanism by which adaptive genes may flow from one to the other, including those conferring insecticide resistance $[7,9]$. In our study, no hybrids have been found out of 403 specimens that were typed. This infers a frequency of hybridisation of less than $1 \%$, although in the An. gambiae complex, hybridisation

Table 3: Scoring of kdr genotypes in An. gambiae M and S-forms. All were homozygous susceptible +/+

\begin{tabular}{lcccc}
\hline Muncipality & site & An. gambiae & S & $+/+$ \\
\hline \multirow{2}{*}{ Benguela } & & 37 & 3 & 40 \\
& Cawango & 80 & 3 & 83 \\
Lobito & Bela Vista & 41 & 0 & 41 \\
Huambo & São Pedro & 27 & 7 & 34 \\
& São Jose & 10 & 10 & 20 \\
& Cazenga & 195 & 23 & 218 \\
\hline
\end{tabular}

Footnote: kdr genotypes were not scored for the 13 specimens from Cacuaco 
Table 4: Plasmodium falciparum sporozoite rates based on ELISA in mosquitoes of the An. gambiae complex and An. funestus collected in Angola

\begin{tabular}{|c|c|c|c|c|}
\hline Municipality & Locality & An. gambiae \% positive (n) & An. melas $\%$ positive $(n)$ & An. funestus $\%$ positive (n) \\
\hline \multirow[t]{2}{*}{ Benguela } & Bela Vista & $0.8 \%(118)$ & - & - \\
\hline & Cawango & $1.5 \%(132)$ & - & - \\
\hline Lobito & São Pedro & $2.5 \%(317)$ & - & - \\
\hline Cacuaco & Funda & $0 \%(13)$ & $0 \%(13)$ & $0.7 \%(140)$ \\
\hline Total & & $1.9 \%(580)$ & $0 \%(13)$ & $0.7 \%(140)$ \\
\hline
\end{tabular}

between species and forms may be more likely at certain seasons as densities are undergoing change.

In this study we tested only 218 An. gambiae s.s. mosquitoes for $\mathrm{kdr}$ resistance and no resistance alleles were found. We did not expect to find resistance to pyrethroids, since these insecticides have not been available in significant quantities during the periods of civil strife, when agricultural production was severely disrupted. Carrara et al. [17] reported "the presence of the $k d r$-allele (about 18\%)" in the Cabinda enclave, but did not find the resistant alleles in samples (of unstated size) from other sites in Angola. Whilst kdr resistance does not yet appear to have a highly significant effect on the performance of ITNs for malaria control, it would be prudent to increase monitoring for resistance using standard WHO bioassays and molecular tests that can detect both metabolic resistance and target site insensitivity $[19,20]$.

\section{Authors' contributions}

NC carried out the field collections of malaria vectors in Angola together with staff of the National Malaria Control Programme. He conducted the laboratory analysis of sporozoite rates and the PCR assays for identification of the An. funestus complex.

NC and KSC jointly carried out PCR assays for species and molecular forms of the An. gambiae complex, and the assays for $k d r$. All assays of molecular forms and kdr resistance were double-checked and any discrepancies resolved. HT advised on the experimental methods, results and interpretation of these assays.

$\mathrm{NC}$ and HT took the lead role in data analysis and interpretation. All three authors were closely involved in writing the paper and read and approved the final manuscript.

\section{Acknowledgements}

The authors wish to thank Dr Filomeno Fortes, head of the National Malaria Control Programme in Angola for providing logistical support for the fieldwork and making available the staff of the Vector Unit to assist in mosquito collections. Pedro Cani from the control programme played an invaluable role in identifying sites for mosquito collections and assisting in the fieldwork. Mosquitoes were collected whilst Nelson Cuamba was on a WHO AFRO mission for "strengthening malaria vector control, especially the promotion of insecticide-treated bednets in Angola". Alexander Egyir-
Yawson (Liverpool School of Tropical Medicine) kindly provided control samples of DNA for each of the kdr genotypes. A research-training award from the UNDP/World Bank/WHO Special Programme for Research and Training in Tropical Diseases supported the laboratory and field studies of Nelson Cuamba.

\section{References}

I. Akogbeto MR: Infectivity of Anopheles melas vis-a-vis Plasmodium falciparum in the coastal lagoon area of Benin. Bull Soc Path Exot 1999, 92:57-61.

2. Bryan J: Anopheles gambiae and A. melas at Brefet, The Gambia, and their role in malaria transmission. Ann Trop Med Parasitol 1983, 77: I- 12.

3. Awolola TS, Okwa O, Hunt RH, Ogunrinade AF, Coetzee M: Dynamics of the malaria-vector populations in coastal Lagos, south-western Nigeria. Ann Trop Med Parasitol 2002, 96:75-82.

4. della Torre AFC, Akogbeto M, Dossou-yovo J, Favia G, Petrarca V, Coluzzi M: Molecular evidence of incipient speciation within Anopheles gambiae s.s. in West Africa. Insect Mol Biol 200I, 10:9-18.

5. Gentile G, Slotman M, Ketmaier V, Powell JR, Caccone A: Attempts to molecularly distinguish cryptic taxa in Anopheles gambiae s.s. Insect Mol Biol 200I, 10:25-32.

6. della Torre A, Tu Z, Petrarca V: On the distribution and genetic differentiation of Anopheles gambiae s.s. molecular forms. Insect Biochem Mol Biol 2005, 35:755-769.

7. Fanello C, Petrarca V, della Torre A, Santolamazza F, Dolo G, Coulibaly M, Alloueche A, Curtis CF, Toure YT, Coluzzi M: The pyrethroid knock-down resistance gene in the Anopheles gambiae complex in Mali and further indication of incipient speciation within An. gambiae s.s. Insect Mol Biol 2003, 12:24I-246.

8. Weill M, Chandre F, Brengues C, Manguin S, Akogbeto M, Pasteur N, Guillet P, Raymond M: The kdr mutation occurs in the Mopti form of Anopheles gambiae s.s. through introgression. Insect Mol Biol 2000, 9:45I-456.

9. Yawson AE, McCall PJ, Wilson MD, Donnelly MJ: Species abundance and insecticide resistance of Anopheles gambiae in selected areas of Ghana and Burkina Faso. Med Vet Entomol 2004, 18:372-377.

10. WHO/UNICEF: World Malaria Report. 2005.

II. Ballinger-Crabtree ME, Black WC, Miller BR: Use of genetic polymorphisms detected by the random-amplified polymorphic DNA polymerase chain reaction (RAPD-PCR) for differentiation and identification of Aedes aegypti subspecies and populations. Am J Trop Med Hyg 1992, 47:893-90I.

12. Fanello C, Santolamazza F, della Torre A: Simultaneous identification of species and molecular forms of the Anopheles gambiae complex by PCR- RFLP. Med Vet Entomol 2002, 16:46|-463.

13. Koekemoer LL, Kamau L, Hunt RH, Coetzee M: A cocktail polymerase chain reaction assay to identify members of the Anopheles funestus (Diptera: Culicidae) group. Am J Trop Med Hyg 2002, 66:804-8II.

14. Martinez-Torres D, Chandre F, Williamson MS, Darriet F, Berge JB, Devonshire AL, Guillet P, Pasteur N, Pauron D: Molecular characterization of pyrethroid knockdown resistance (kdr) in the major malaria vector Anopheles gambiae s.s. Insect Mol Biol 1998, 7:179-184.

15. Burkot T, Williams JL, Schneider I: Identification of Plasmodium falciparum- infected mosquitoes by a double antibody 
enzyme-linked immunosorbent assay. Am J Trop Med Hyg 1984, 33:783-788.

16. Wirtz R, Zavala F, Charoenvit Y, Campbell GH, Burkot TR, Schneider I, Esser KM, Beaudoin RL, Andre RG: Comparative testing of monoclonal antibodies against Plasmodium falciparum sporozoites for ELISA development. Bull World Health Organ 1987, 65:39-45.

17. Carrara GC, Santolamazza F, Fanello C, Cani PJ, della Torre A, Petrarca V: Preliminary data on Anopheline malaria vectors at two sites of Western Angola. Parassitologia 2002, 44:43.

18. Townson H, Nathan MB, Zaim M, Guillet P, Bos R, Kindhauser M: Maximizing the preventive power of disease vector control. Bull World Health Organ 2005, 83:942-947.

19. David JP, Strode C, Vontas J, Nikou D, Vaughan A, Pignatelli PM, Louis C, Hemingway J, Ranson H: The Anopheles gambiae detoxification chip: A highly specific microarray to study metabolicbased insecticide resistance in malaria vectors. Proc Natl Acad Sci USA 2005, 102:4080-4084.

20. Lynd A, Ranson H, McCall PJ, Randle NP, Black WC, Walker ED, Donnelly MJ: A simplified high-throughput method for pyrethroid knock-down resistance (kdr) detection in Anopheles gambiae. Malar J 2005, 4: I6.

Publish with Bio Med Central and every scientist can read your work free of charge

"BioMed Central will be the most significant development for disseminating the results of biomedical research in our lifetime. "

Sir Paul Nurse, Cancer Research UK

Your research papers will be:

- available free of charge to the entire biomedical community

- peer reviewed and published immediately upon acceptance

- cited in PubMed and archived on PubMed Central

- yours - you keep the copyright

Submit your manuscript here:

http://www.biomedcentral.com/info/publishing_adv.asp 